\title{
Transit integrated housing in Cyprus
}

\author{
A. Savvides \\ Department of Architecture, University of Cyprus, Cyprus
}

\begin{abstract}
The connection between improved public transit and mobility on the fundamental trip between residence and workplace or leisure becomes especially important as gasoline prices - affecting the users of private automobiles become prohibitive. Whereas before the crisis housing development locations may have been affected predominantly by land values, post crisis development may be shifting towards the proximity to public transportation infrastructure in order to offset enhanced mobility costs. Transportation nodes, from their initial inception, have been organizing forces in a city's housing development policies. At the same time, driving and the use of highways has been a fact of life for many people in Cyprus who live in circumstances that demand car travel. At the community level, local governments are beginning to establish development policies to promote this enhanced connectivity by relating transportation cost savings resulting from new housing development at points of exchange that allow enhanced connectivity to the primary destinations of work and basic services. Incentives used for new development to locate near transit lines and stations are explored, as are design guidelines for projects aimed at improving access beyond public transit stations to a network of arterial roads that improve mobility options. Alternatives in the use of the automobile to connect local destinations are investigated, such as at the nodal points of education, healthcare and retail and professional services.

Keywords: social housing, housing policies, housing finance, housing demand indicators, transit oriented development.
\end{abstract}

\section{Introduction}

Cyprus in general and the Nicosia Capital Region in particular, as a result of the economic crisis that has significantly affected the housing market, have prompted initiatives and policies to couple and revisit the topics of transportation 
and land use. These initiatives in conjunction with an increasing demand for transit-adjacent housing, puts pressure on governmental organizations - such as the pertinent public troika of the Department of Housing and Planning, the Land Development Corporation and the Housing Finance Corporation - to expand their offerings of housing stock, which is both affordable and well connected to the urban transportation network. This becomes especially important given plans to introduce a light rail or tram and/or bus rapid transit system in four major transportation corridors in the Nicosia Capital Region.

This is a phenomenon that has been observed to increasingly occur as of late due to the financial constraints that have been placed on urban households as a result of the financial crisis. One pertinent example is reported by Audrey Desmuke [1] who notes that as recently as May of 2012, the Los Angeles Housing Department, in collaboration with the organization Reconnecting America, released a study on the Preservation in Transit-Oriented Districts with the goal of ensuring that all families and workers are able to move to or to continue to live and work in transit rich neighborhoods. One way to achieve this goal is to preserve existing affordable housing and rent stabilization ordinance (RSO) housing stock near transit centers $[2,3]$, as the principle of economic competitiveness relies on offering housing for workers of all incomes and low-and-moderate-income workers demand additional housing adjacent to an efficient transit system.

\section{The case of Cyprus - demographic overview and microeconomic background}

According to the International Union for Housing Finance 2011 report [4], Cyprus has approximately eight-hundred-thousand inhabitants. Over the last five years its population has experienced positive growth, mainly through a high migration rate, although this rate has steadily declined from $2.3 \%$ in 2005 to $0.2 \%$ in 2009. The largest age group is that of those aged between 21 and 44 years $(36.7 \%)$, followed by those under $21(26.5 \%)$ and then by those aged between 44 and $65(24.8 \%)$. However, given that most of the migration received in the last few years has been middle-aged or elderly people, the country will have to face a rapidly aging population, which will affect its housing and mobility needs and may represent a burden for future public sector budgets.

Cyprus experienced a high level of economic growth between 2005 and 2008 with an average real GDP growth rate of $4.18 \%$. That period was characterized by austerity plans that would eventually allow the country to join the euro in January 2008. Nevertheless, this growth was abruptly discontinued following the global financial crisis, which saw the country fall into a recession with a negative growth rate of $-1.7 \%$ in 2009 , mainly due to the slowdown in the tourism and construction sectors. The unemployment rate, which had also been decreasing over the last five years, rose in 2009 to the same level as it was in $2005(5.3 \%)$ and continues to rise. The inflation rate had been stable at approximately $2.15 \%$; however, it witnessed a $102.8 \%$ increase in 2008 (caused by high commodity 
prices and an increase in final demand) and then dropped to a value of $0.17 \%$ in 2009. The service sector is the major contributor to the GDP of the country, representing $78.9 \%$ of GDP and accounting for $71 \%$ of the labor force. The drivers of the service sector are financial services, real estate and tourism and a slowdown in these sectors has clear effects on the country's economy, which currently has an increasing budget deficit, thereby infringing the EU's budget criterion which seeks to limit such deficits to no more than $3 \%$.

Cyprus has approximately 375,000 dwellings, which accommodate 275,000 households, the average size of which is 2.8 people. This high ratio of dwellings versus households was highly influenced by the boom years, when approximately $6 \%$ of the GDP was dedicated to investments in housing. Despite the fact that the growth rate of the real fixed investment in housing was negative in 2008 and in 2009, in 2009 there were 18,200 house completions and 16,700 new building permits were issued. Therefore, there does not seem to be a housing supply shortage in the country at present. What a perceived anomaly may be, however, is the location of the affordable housing units within this stock and their proximity or easy access to the work place, not to mention the increasing need to utilize public transit rather that a private vehicle for the trip to services and the workplace. The data is from the March 2013, Eurostat, main tables and database report [5] and indicate distribution of population by dwelling type, tenure status, overcrowding rate and severe housing deprivation. Though the values for Cyprus stand it in good stead, these are worsening as a result of the crisis with all indicators shown on the rise.

\subsection{Housing market: tenure, loans and government policies}

The division of the island into the Greek and Turkish areas in 1974 has led to a variety of atypical tenure categories, such as refugee estate, a Turkish Cypriot house and self-help schemes aimed at refugees. Housing of the persons who have not been affected by the enforced division and displacement is mainly provided by the private sector, but a number of low-cost housing schemes have also been introduced since the 1980 s, aimed mainly at supporting low to middle income families acquiring a home [6]. Dwellings are mainly owner-occupied (61.8\%). Otherwise, they are primarily rented from private landlords (18.7\%).

Therefore, the rental market of properties owned by the government or by social landlords is not overly developed in Cyprus. In any case, the quality of most dwellings is very high given that more than half of the country's stock has been built since the 1980s. In Cyprus, the main lending institutions are the commercial and the cooperative banks, which offer both variable and initially fixed rate mortgages. Currently, the representative interest rate on new mortgage loans is $4.82 \%$ and the residential mortgage debt to GDP ratio is $74.44 \%$, which suggests a developed housing finance system. This ratio rapidly increased over the last five years, and in October 2009 this ratio was three times higher than that observed in December 2005. Nevertheless, it seems that this rapid growth will not continue in 2010 as demand has recently been falling and banks have been tightening their lending standards. 
Funding of housing loans comes mainly from bank deposits. The Government of Cyprus is currently preparing legislation for the establishment of a covered bond market in order to enable financial institutions to issue covered bonds for the financing of mortgage loans. Cyprus sets transfer and stamp duty taxes on house purchases, whereby buildings are subject to VAT at $15 \%$. There is also an annual property tax and a tax on capital gains at the moment of the sale of the dwelling. However, there are a number of government actions such as a grant for dwellings of less than 250 square meters, subsidized prices or reduced interest loans, in line with the country's policy to promote owner occupation, which particularly benefits low and middle-income households.

\subsection{Social housing in Cyprus}

Most housing in Cyprus is provided by the private sector, which offers a variety of residential options, generally affordable to different income groups [7]. In order to support and supplement the private sector, the government established in 1982 the Cyprus Land Development Corporation (CLDC.) and the Housing Finance Corporation (HFC.). The objectives of the two corporations are respectively to supply building plots or houses at reasonable prices and provide long-term housing loans (with lower interest rates for low-income groups). Furthermore, today 13,500 refugee-households are still living free of charge in housing estates constructed and maintained by the government. Both agencies work jointly towards enabling medium and low-income groups to acquire a home. The Cyprus Land Development Corporation builds and sells houses and building plots at a subsidized price to medium and low-income households, while the Housing Finance Corporation and the government provide low interest loans to the purchasers of these dwellings. The provision of housing for families displaced as a result of the partition of the island in 1974 has also been a key priority for government. Since then, approximately 75,000 families have been provided with shelter or assisted to acquire a new house by the State.

\subsection{Access to social housing in Cyprus}

Up to now displaced families and refugees, low-income families and persons living in disadvantaged areas have been the main target groups of most current social housing schemes. However, given the stricter lending criteria in Cyprus in face of the crisis, as mentioned above, the private sector continues to restrict access of households to housing loans in 2013 and in the foreseeable future, as credit institutions continue to adopt stricter lending criteria for housing loans to households. This puts Cypriot families between a rock and a hard place, especially given that in the case of Cyprus, the concept of social rental housing is not clearly established. In the past, the government has, from time to time, implemented a number of housing schemes with the purpose of assisting various social groups, but there has been no comprehensive policy framework to date. New housing schemes are now being introduced for a wider range of target 
groups including large families, low-income families including recipients of public assistance and persons with disabilities, evaluating the financial impact of access to housing for these vulnerable communities as evidenced in Table 1 below [8].

Table 1: Degree of severity of financial impact of access to housing on family income ( $\%$ by categories of population - 'large', 'small' and 'no' impact on the vertical scale by year (rows) \& ' $\%$ of total' population, ' $\%$ of poverty level segment' and ' $\%$ of non-poverty level segment' of the population on the horizontal scale (columns). Source: Cyprus Statistical Service (CyStat).

\begin{tabular}{|c|c|c|c|c|}
\hline Year & $\begin{array}{c}\text { Financial Impact of } \\
\text { Access to Housing }\end{array}$ & $\begin{array}{c}\% \\
\text { Total }\end{array}$ & $\begin{array}{c}\text { \% Poverty } \\
\text { Level Segment }\end{array}$ & $\begin{array}{c}\text { \% Non-Poverty } \\
\text { Level Segment }\end{array}$ \\
\hline 2008 & Large Impact & 67.4 & 79.7 & 65.1 \\
\hline & Small Impact & 29.3 & 17.5 & 31.6 \\
\hline & No Impact & 3.2 & 2.8 & 3.3 \\
\hline 2009 & Large Impact & 63.8 & 76.3 & 61.5 \\
\hline & Small Impact & 28.7 & 18.6 & 30.6 \\
\hline & No Impact & 7.5 & 5.2 & 7.9 \\
\hline 2010 & Large Impact & 69.4 & 76.9 & 68.1 \\
\hline & Small Impact & 26.0 & 18.1 & 27.4 \\
\hline & No Impact & 4.6 & 5.0 & 4.6 \\
\hline 2011 & Large Impact & 72.7 & 81.2 & 71.3 \\
\hline & Small Impact & 23.0 & 15.2 & 24.3 \\
\hline & No Impact & 4.3 & 3.6 & 4.4 \\
\hline
\end{tabular}

The opportunity therefore exists to profile the users falling in the category outlined above and to integrate housing and transit-oriented development as a strategy in facing the effects of the crisis on access to housing by those vulnerable groups in the Cypriot community.

\section{Integrating goals for improved mobility with the development of social housing}

In deciding who may be best suited to integrate goals for improved mobility with the development of social housing using the transit oriented development model as a catalyst, may not be a simple matter. On one hand, research, such as that carried out at the University of California Transportation Center, reveals that there exists a significant ridership bonus associated with transit oriented living and further suggests that residential self-selection significantly accounts for this 
bonus [9]. On the other hand, self selection does not diminish the importance of planning for and building transit-oriented residences. If the marketplace functioned perfectly, then a case might be made for governments to get out of the way so that producers and consumers can sort themselves into station areas unfettered. However, marketplaces are not perfect, whether due to private developers' inability to finance new construction, exclusionary zoning, imperfect information or negative externalities and other such frictions to residential mobility suggest that there exists a legitimate role for the public sector - and in the case of Cyprus the troika of public authorities mentioned above - in breaking down barriers to help nurture TODs. Findings of self selection underscore the importance of introducing market-responsive zoning in and around transit nodes - zoning that acknowledges that those living near transit tend to be in smaller households with fewer cars and who rely on public transit to get to work and to access good and services.

The research team at the University of California Transportation Center presents case studies conducted in several U.S. rail cities - notably San Diego and Mountain View, California, Portland, Oregon, Bethesda, Maryland and Arlington, Virginia - which have pro-actively zoned for housing near rail stations [10]. Most of these case studies, however, also show that these communities in order to maximize economic development have focused on zoning for commercial development in hopes of producing higher property tax receipts than normally yielded by transit oriented housing projects [11]. On the other hand though and besides supportive zoning, a number of other recent public policy initiatives have been mentioned with the aim of prompting the development of transit-based housing. A noteworthy federal action in the U.S. has been the allowance of transit agencies to sell land, such as parking lots, to private interests for the purpose of converting parking lots to housing and to date, transit properties in Washington, D.C., Atlanta, Portland, Southern California and the San Francisco Bay Area have used this opportunity to leverage affordable housing projects on former parking lots.

In the San Francisco Bay Area, several public agencies have been especially proactive in promoting transit-based housing. For example, an entity known as the Metropolitan Transportation Commission has set aside $€ 6.67$ million under a Housing Incentive Program (HIP) as grant funds for local jurisdictions that locate compact housing near transit. To qualify for funds, a proposed housing project must be within a half kilometer walk of a rail or tram station or bus route and provide at least a dozen units per hectare. Grants of $€ 1500$ per unit are being provided for projects built at twenty five and higher units per hectare. Several Bay Area cities have used HIP grants to raise densities and increase the affordable component of transit-based housing projects. Even sub-regional governments have introduced incentive programs. The San Mateo City-County Association of Governments (C/CAG) authorizes $€ 1500$ in State Transportation Improvement Program (STIP) funds for each bedroom built within half a kilometer of a rail station and at a density of 20 units per net hectare or more. In fiscal year $2000-2001$, more than $€ 1.63$ million of STIP funds were transferred 
to local governments as a reward for adding more than 1,200 bedrooms in high-density housing near rail stops.

Lastly, the research above underscores the importance of targeting workplaces, not just residences, to rail station areas. For TODs to have a substantial impact, they must provide accessibility advantages over the private car, something which occurs by putting more destinations, like workplaces, near stations in addition to providing fast, frequent, and reliable transit services. Placing work sites near transit, however, is not enough. Free employee parking and other car subsidies will often prompt even those who live near transit to solo-commute. In Cyprus, at least, given the plans to introduce rail transit and park-and-ride facilities at key locations along proposed transportation corridors in the Nicosia Capital Region, the troika of public entities mentioned above must promote employer-based policies that eliminate free parking and provide good pedestrian access to the workplace if TOD is to draw significant numbers of residents to trains and buses.

\subsection{Trip reduction impacts of transit-oriented housing}

Clear policy directions fall out of the research work above and the appreciably lower trip generation rates of transit-oriented housing projects call for adjustments in the measurement of traffic impacts. For peak periods (that often govern the design of roads Vehicle Trip Reduction Impacts of Transit-Oriented Housing and highways), the research shows that transit-oriented apartments average around one half the norm of vehicle trips per dwelling unit [12] and the communities that promote smart growth principles in their urban design guidelines that lower the need to make vehicle trips should be rewarded in the form of reduced traffic impact fees and exactions. The expectation is that developers, private or public such as the Cyprus Land Development Corporation, would pass on some of the cost savings to tenants, thus making housing more affordable near transit stations.

The research above also indicates that the trip-reducing benefits of TOD call for other development incentives, such as flexible parking codes, marketresponsive zoning, streamlining the project review and permitting process and investments in supportive public infrastructure. Evidence of trip de-generation also suggests TODs are strong markets for car-sharing. Recent research in the San Francisco Bay Area reveals that those who participate in car-sharing lower their car ownership levels by around 10 percent, with higher vehicle-shedding rates among those living near rail stations [13]. The failed Plus-Two for the Limassol Avenue corridor in Nicosia did indeed have as an aim to combine reduced off-street parking and increased car-sharing options that would have yielded other benefits, including reducing the amount of impervious surface (and thus water run-off and heat island effects) and the creation of more walkable scales of development. Such practices may be seen as market-oriented responses with the aim of setting design standards and providing housing and mobility options that are in keeping with the market preferences of those who chose to or benefit the most from living near transit. 


\subsection{The effects of TOD on affordable housing, job accessibility and affordability of transportation}

Studying the effects of transit orient development on affordable housing, job accessibility and affordability, Audrey Desmuke quoted the work of Sanchez and Brenman [14] wherein they note that transportation equity - as defined by a range of strategies and policies aimed to address inequities in transportation planning and project delivery system - stems from environmental justice, metropolitan equity and the just distribution of resources. Desmuke also quoted the work of Michael Kralovich [2], who wrote a paper on developing strategies for equitable TOD and its benefits to society. In the study that followed, equitable transportation was seen as:

- Ensuring opportunities for meaningful public involvement in the transportation planning process, particularly for those communities that most directly feel the impact of projects or funding choices.

- Holding public accountability and financial transparency to a high standard, especially where vulnerable segments of the population are concerned.

- Distributing the benefits and burdens from TODs across all income levels and communities, but perhaps with a special consideration to vulnerable segments of the population in a time of crisis.

- Providing high-quality services - emphasizing access to economic opportunity and basic mobility - to all communities, but with an emphasis on transit-dependent populations.

- Prioritizing efforts both to revitalize poor and transit-dependent communities and expanding transportation infrastructure in an equitable manner.

Protection of vulnerable populations, e.g. residents and workers with lowerincomes who rent, is important because they are more likely to make up core transit riders. In other words, promoting and preserving a diverse transit-rich neighborhood is crucial to the success of TODs that aim at integrating housing and transit-oriented development in a time of crisis.

\subsection{Job accessibility in TODs}

Employment proximity can be attributed to the reduction in vehicle miles travelled (VMT) when transit zones are located close to housing and employment destinations. This is an issue of special concern as by concentrating jobs in closer proximity to transit stations and transit closer to employment clusters, the troika of public agencies responsible for social housing production in Cyprus may help to diversify employment opportunities for the car-less, lowincome workers and provide better access to job opportunities. In some cases, a low VMT place is proximate to ten times more jobs than places with high VMT [15].

In fact, according to Reconnecting America's Center for Transit-Oriented Development, one of the five essential strategies for capturing maximum 
commuter trips by transit is making sure employment sites are close to transit and that they meet fundamental location criteria of transit-oriented industries. In the same study, it was found that about 59 percent of transit trips are for the purpose of work [16]. Even though jobs are difficult to quantify and are highly flexible, information on job centrality can relate high-density housing and workplace hubs with high transit ridership [17] and transit's share of the commute trip is highly correlated with population and employment density.

\section{Integrating affordable housing and transportation: concluding thoughts}

Housing and transportation costs are reaching levels whereby traditional rents and home prices are getting out of the reach of families who live and work in the Nicosia Capital Region and other major metropolitan areas in the other districts in Cyprus. A significant number of these families spend more than half of their monthly income on rent and transportation by private vehicle is the second largest expense after paying for housing, making them vulnerable to displacement. Studies [18] have been indicating that households in auto-dependent neighborhoods spend about 25 percent of their income of transportation costs compared to households with good access to transit who spend only about 9 percent.

A shift in the housing market is occurring because traffic congestion during the commute to work and back home in the suburbs has become so bad that the commute is no longer desirable or an affordable option. Augmenting and building new affordable housing near transit hubs enables a household to save money on both transportation and housing expenditures [18]. An ideal model to follow may be the Location Efficient Environment (LEE), sponsoring environments where neighborhoods are compact with walkable streets, access to transit and a variety of amenities and services within a short walk. The model was developed in 1995 by the Institute for Location Efficiency (ILE), which also devised a Location Efficient Mortgage (LEM) mechanism, created to subsidize low-income home buyers who wanted to live near transit centers, where development is compact and accessible [19]. LEM is a type of mortgage that recognizes the potential costs savings from living near transit (like reduced vehicle use) and therefore allows a home buyer to purchase a more expensive house than a traditional mortgage would allow. In 2011, it was reported [19] that LEMs were not being offered. Housing is considered affordable if it costs less than 30 percent of household income [18]. In the City of Los Angeles in 2006, it was reported that 32 percent of family income is spent on housing, while 27 percent of family income is spent on transportation [16].

Savings on transportation costs are getting to be a necessity for low-income households who may be spending a greater percentage of their incomes on transportation than other income groups. For these reasons, station area plans should focus specifically on mixed-income housing, such as the proposed mass transit corridors and park-and-ride facilities planned for the Nicosia Capital Region as shown in Figure 1 [20]. 


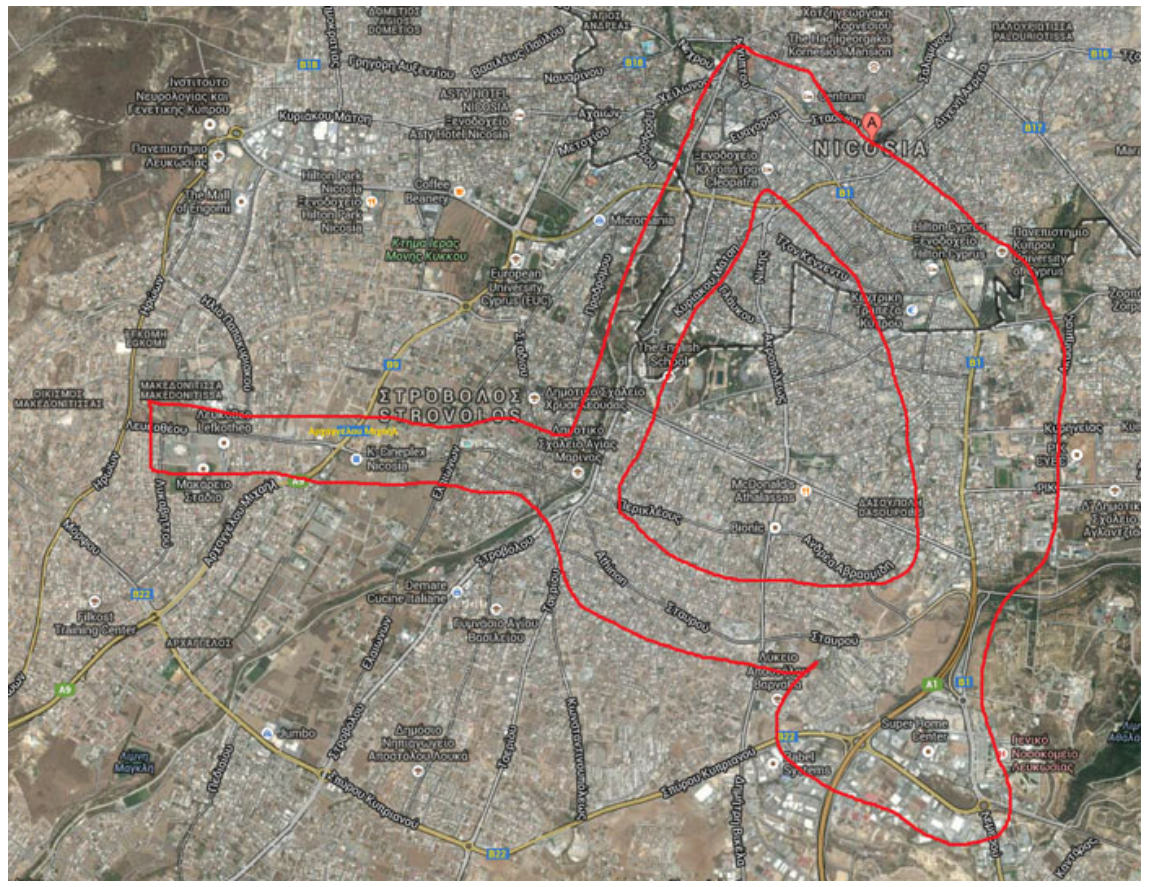

Figure 1: $\quad$ LRT and BRT corridors proposed for the Nicosia Capital Region. Source: Ministry of Communications and Works.

In fact anywhere between 15-20\% percent of household income may be saved on transportation expenses if affordable housing is located near transit hubs [21]. Strategies such as inclusionary zoning, which increase density and lower parking requirements for new projects near transit stations can capture the value of transit and create value for developers through incentives and linkage programs that allow them to build more affordable units or to provide public amenities.

\section{References}

[1] Desmuke, A. M. Effects of transit-oriented development on affordable housing, job accessibility and affordability of transportation in the metro green line corridor of Los Angeles, Thesis, California Polytechnic State University, San Luis Obispo, June 2013.

[2] Kralovich, M. Cultivating successful transit-rich communities in Los Angeles: strategies for equitable TOD. Urban and Environmental Policy Senior Comprehensive Project, Martha Matsuoka \& Bhavna Shamasunder, Occidental College, Los Angeles, CA, March 2012. 
[3] Reconnecting America. Preservation in transit-oriented districts: a study on the need, priorities \& tools in protecting assisted \& unassisted housing in the City of Los Angeles. Accessed on 11/13 at: http://www.reconnectingamerica.org/assets/PDFs/20120524LAHDTODPr eservationFinal.pdf

[4] International Union for Housing Finance. Fact sheet > Cyprus, Member contributor: Housing Finance Corporation Cyprus, Date of Publication: October 2010. Accessed on 11/13 at: http://www.housingfinance.org/ housing-finance/facts-and-figures

[5] Eurostat. Housing Statistics, Accessed on 11/13 at: http://epp.eurostat.ec. europa.eu/statistics_explained/index.php/Housing_statistics

[6] Norris. M. and Shiels, P. Regular National Report on Housing Developments in European Countries, Synthesis Report, The Housing Unit, Dublin, Ireland, November 2004.

[7] Pittini, A. and Laino, E. Housing Europe Review 2012: the nuts and bolts of European social housing systems, CECODHAS Housing Europe's Observatory, Brussels, Belgium, October 2011.

[8] CyStat. Household income and living conditions survey: 2008-2011, General Social Statistics, Series II, No. 5, February, 2013, pp. 30-31, 2013.

[9] Cervero, R. Transit oriented development's ridership bonus: a product of self-selection and public policies, Earlier Faculty Research, University of California Transportation Center, UC Berkeley, CA, September 2006.

[10] Cervero, R., Ferrell, C. and Murphy, S. Transit-oriented development and joint development in the United States: a literature review. Research Results Digest. Washington, D.C., Transportation Research Board, Transit Cooperative Research Program, No. 52, 2002.

[11] Boarnet, M. and Crane, R. Public finance and transit-oriented planning: new evidence from southern California. Journal of Planning Education and Research, Vol. 17, pp. 206-219, 1998.

[12] Cervero, R. Vehicle Trip Reduction Impacts of Transit-Oriented Housing, Journal of Public Transportation, Vol. 11, No. 3, 2008.

[13] Cervero, R., Golub A. and Nee, B. City car-share: longer-term traveldemand and car ownership impacts, Transportation Research Record, 1992, pp. 70-80, 2007.

[14] Sanchez, T. and Brenman, M. The right to transportation: moving to equity. American Planning Association, Chicago, IL, Planners Press, 2007.

[15] Austin, M., Belzer, D., Benedict, A., Esling, P., Haas, P., Miknaitis, G., Wampler, E., Wood, J., Young, L. and Zimbabwe, S. Performance-Based Transit-Oriented Development Typology Guidebook, Center for Transit Oriented Development, Chicago, IL, 2010.

[16] Reconnecting America's Center for Transit-Oriented Development. Mixed-income housing near transit. Washington, DC, Federal Transit Administration, 2008. 
[17] Nelson/Nygaard Consulting Associations. Resolution 3434: TransitOriented Development Policy, 2007 Evaluation prepared for the Metropolitan Transportation Commission, 2007.

[18] Reconnecting America's Center for Transit Oriented Development \& Center for Neighborhood Technology. The affordability index: a new tool for measuring the true affordability of a housing choice, Metropolitan Policy Program, Center for Transit-Oriented Development, 2009.

[19] Reconnecting America's Center for Neighborhood Technology. Location Efficient Mortgage (LEM). Accessed on 11/13 at: http://www.cnt.org/tcd/location-efficiency/lem

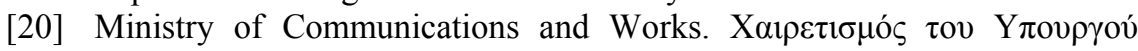

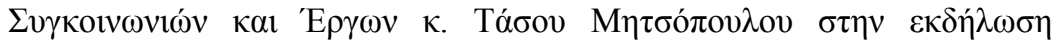
« 30/05/2013

[21] Belzer, D., Srivastava, S., Wood, J., Greenberg, E. Transit-Oriented Development (TOD) and Employment. Center for Transit-Oriented Development, Chicago, IL, 2011. 